Article

\title{
Understanding Sustainable Forest Management Certification in Slovakia: Forest Owners' Perception of Expectations, Benefits and Problems
}

\author{
Hubert Paluš ${ }^{1, *(\mathbb{D})}$, Ján Parobek ${ }^{1}$ (D), Rastislav Šulek ${ }^{2}$, Ján Lichý ${ }^{2}$ and Jaroslav Šálka 2 (1) \\ 1 Department of Marketing, Trade and World Forestry, Technical University in Zvolen, T. G. Masaryka 24, \\ 96053 Zvolen, Slovakia; parobek@tuzvo.sk (J.P.) \\ 2 Department of Economics and Management of Forestry, Technical University in Zvolen, T. G. Masaryka 24, \\ 96053 Zvolen, Slovakia; sulek@tuzvo.sk (R.Š.); jan.lichy@tuzvo.sk (J.L.); salka@tuzvo.sk (J.Š.) \\ * Correspondence: palus@tuzvo.sk; Tel.: +421-455-206-444
}

Received: 5 June 2018; Accepted: 13 July 2018; Published: 14 July 2018

check for updates

\begin{abstract}
Forest certification as a voluntary verification tool has been providing an independent assessment of sustainable forestry practices and thus confidence in sustainability benchmarks for over 20 years. Using either the international or national approaches and initiatives, two main forest certification systems, PEFC (Programme for the Endorsement of Forest Certification) and FSC (Forest Stewardship Council), have spread in a number of countries worldwide. The specifics of local conditions in the forestry sector have to be taken into account when implementing the certification context in a given country or a region. Apart from the natural conditions, institutional structure, or legislative framework, it is also the local and national stakeholders and their perception of this issue that provides the background for the implementation of the certification criteria. The main objective of this study is to examine the general understanding of the certification concept as an environmental, economic, and social tool, and to determine the incentives of forest owners in Slovakia for sustainable forest management (SFM) certification. In addition, the benefits and problems arising from participation in certification were identified and differences reflecting the ownership structure of forests, size of forest area, and participation in a particular certification programme were analysed. Results indicate that certified forest owners, unlike non-certified, demonstrated a high level of understanding of the SFM certification concept. Certified entities mainly consider forest certification as their commitment to environmental responsibility and a tool for improving external company image, promoting sustainable utilisation of forest resources, and improving forest management practices. The main benefits are linked to the possibility to demonstrate forest management practices, a better understanding of the forest management concept, and improvement of forest management practices. PEFC users perceive more benefits following from certification; the most important are those associated with non-economic values, while FSC-certified forest owners perceive mainly economic benefits connected to market penetration, increased sales volume, and potential price premiums. The key problems associated with certification relate to duties to ensure compliance with certification criteria by contractors and administrative difficulties. Respondents reported minimum price premiums for the sale of their certified timber. Additionally, the findings of the study pointed out that a nationally developed certification system can better recognise the roles and objectives of forest certification in the context of forest policy.
\end{abstract}

Keywords: sustainable forest management; forest certification; certified forest owners; certification cost 


\section{Introduction}

\subsection{Forest Certification and Sustainability}

Sustainable forest management (SFM) is based on the concept of sustainable development and integrates three equally important pillars: environmental soundness, social justice, and economic viability [1]. The concept of sustainable development was originally popularized in the Brundtland report [2] and finally developed at the Rio Earth Summit in 1992 where the non-legally binding Forest Principles [3,4] initiated forest certification. Thus, forest certification was initially introduced as a voluntary mechanism by environmental groups to ameliorate the consequences of tropical deforestation and forest degradation [4]. Forest certification, a mechanism based on third-party auditing of compliance with established standards, was quickly accepted as a means to promote sustainable forest management [5-7] and directly influenced forest management practices [8-11]. Through certification as a soft policy instrument $[12,13]$, it is possible to provide credible assurance to customers about the effective compliance of forest management with sound social, environmental, and economic principles [14-16]. However, as sustainable development is a continuous process and its concept is further adjusted according to new knowledge, sustainability indicators are continuously improved in order to achieve credibility and legitimacy within society through a wider form of participation involving citizens or their representatives [17]. One of the examples is the indicator "Forest area under an independently verified forest management certification scheme" that is one of the sub-indicators of the Sustainable Development Goals (SDG) Indicator 15.2.1-Progress towards sustainable forest management, within the United Nations 2030 Agenda [18].

As the certification focuses on aspects of sustainability, it has links with a whole range of issues that can be addressed through national policies. Nussbaum and Simula [12] identified several policy issues having relevance to certification such as responsible or sustainable forest management, the balance between economic, social and environmental concerns for forest management, illegal harvesting, conservation of biodiversity, timber markets, and so forth. From the forest policy point of view, certification can contribute to wider policy debate, support stakeholder participation, and integration of policies, as well as contribute to the improvement of national forestry [13]. The impact of certification is greater in cases where national standards are developed as they can be viewed as processes of mutual learning and influence public policy [12]. Forest certification is a process by which forest owners voluntarily submit their forests for inspection by an independent certification body to determine whether their management practices meet clearly defined standards, particularly those regarding sustainability [19]. Ulybina and Fennell [20] suggest certification is a signal to external stakeholders that enterprises are meeting high forestry standards or improving forestry practices and/or production. Rickenbach and Overdevest [16] view forest certification as a market-based incentive for forestry enterprises as firms adopting certification practices expect direct market benefits. Advantages of market access shall also offer sufficient incentives for suppliers to bear the costs of certification [21]. Decisions to participate in certification programmes can be positively influenced by a number of different factors, for example, receiving professional advice or having a written management or stewardship plan [22], market pressure, land-ownership pattern, and water-body abundance [23]. Galati et al. [24] argue that influence of internal drivers to adopt voluntary certification linked to a pro-environmental behaviour of owners and managers, such as a signalling mechanism and moral and ethical reasons, is more important than economic or market incentives. Empirical results by Nakamura et al. [25] and Takahashi [26] revealed that the market economic and social models explained participation in forest certification.

Promotion of SFM through forest certification may partly depend on the extent of perception of a market-based incentive to supply certified products $[27,28]$. Many survey-based studies have evaluated the willingness to pay for certified wood products [29-39] and indicated a level of price premium that consumers were willing to pay for different wood products in specific market segments. Apart from the promotion of sustainable forest management practices and the satisfaction of supporting 
the sustainability of natural forest resources and society as a whole [40], benefits following from the adoption of forest certification are related to the improvement of the external companies' image associated to their environmental performance $[11,34,35,37,41-43]$ and environmental communication and consumer relations [44-47].

Timber legality legislation, such as the European Timber Regulation (EUTR), incorporates forest certification as an acceptable measure for the legality verification of wood and wood products, in particular, concerning risk assessment and risk mitigation procedures as a part of an operator's due diligence system [48]. Implementation of forest certification into this system could contribute to reduced costs and administrative work for operators [49]. Cashore and Stone [50] state that EUTR as a public policy may potentially have a positive effect on the acceptance of certification. Moreover, companies certified in the supply chain link forest certification mainly to the issues of legality, tracing, the origin source of supply and prevention from illegal logging [34,35].

The adoption of voluntary forest certification by forest owners may result in additional costs related to the standards implementation, initial and surveillance conformity assessment through internal and external audits, and cost resulting from the changes to the traditional forest management practices caused by the certification requirements [51]. Increased costs of certification are, thus, one of the main barriers for the adoption of forest certification for forest owners as well as for the chain of custody $(\mathrm{CoC})$ level $[11,43,52-55]$. The unit cost is relatively higher for small compared to large forest owners [56]; however, certified forest owners believe that certification benefits exceed costs [42,56].

The PEFC (Programme for the Endorsement of Forest Certification) and FSC (Forest Stewardship Council) global certification systems, as internationally accepted standards consisting of ecological, social, and economic requirements, have evolved, improved and have continually incorporated interrelated concepts and the needs of society. Both certification programmes steadily became an instrument of government procurement policies, obligatory requirements for awarding ecolabels, corporate policies of private companies, requirements for green building initiatives, as well as tools for proving the legality of timber origin and so forth [35].

\subsection{Forest Certification in Slovakia}

Despite research that has been carried out worldwide, there is limited information on the awareness and perception of forest certification in Slovakia. In particular, although there have been some studies focusing on sustainable forest management certification $[43,57,58]$, only a few concentrating on the attitudes of certified $\mathrm{CoC}$ companies towards forests and $\mathrm{CoC}$ certification $[34,35,43]$ and a study aimed at the perception of certified forest products by end users [59].

In Slovakia, forest certification started to develop at the beginning of the 21st century. In 2001, the first forest district of the state forest enterprise LESY SR, š.p. with the area of 40,000 ha was certified by FSC. FSC forest certification in Slovakia uses the international FSC principles and criteria adopted for Slovakia by the standards of individual certification bodies [60]. In 2003, the national FSC initiative was launched to develop national FSC forest management standards. However, recently, the process of development of national FSC standards has paused and the national initiative was cancelled. By the end of 2017, there were 10 valid individual and group FSC sustainable forest management certificates covering the area of 146,832 ha [61] which represents $7.5 \%$ of the total forest area in Slovakia.

The national forest certification system, aiming to achieve the endorsement by the PEFC Council, started to be developed in 2002 when the Slovak Forest Certification Association, later renamed to PEFC Slovakia, was established. In 2004, the Slovak Forest Certification System (SFCS) was internationally endorsed by PEFC for the first time and by the end of 2017, there were 1,232,521 ha of forests $(61.1 \%$ of the total forest area) certified under this scheme [62]. At the same, time the double certified area reached 104,873 ha $(5.2 \%)$. The PEFC certification system is dominant in Slovakia as it reflects the national system of institutional arrangements, best practice in forestry operations, and local natural, social, and economic conditions. It allows all stakeholders to participate in the process of the development 
of national certification criteria and, through its group approach, it allows individual forest owners, regardless of the size and ownership, to participate in regional certification [51].

Currently, in Slovakia, all property regimes and ownership structures participate in PEFC certification. Historically, forest land in Slovakia has been owned by the state, legal entities, and private persons. Therefore, the Slovak forestry sector is divided into two categories: there is a state forestry sector (with typical state ownership of forests) and a non-state forestry sector which includes private forests, community forests, municipal forests, and church forests. Forests in Slovakia cover an area of 1.94 million ha of land. In 2016, the state sector owned 39.7\% of forest land, however, due to a rather significant portion of forest land belonging to non-state forest owners who are either not able or do not want to manage it by themselves, state forest enterprises managed $53.1 \%$ of the total area of forests. The total increment was 12.1 million $\mathrm{m}^{3}$ and volume of felled timber reached 9.32 million $\mathrm{m}^{3}$, of which state forest enterprises produced $52 \%$ and non-state forest owners $48 \%$, respectively. All forest enterprises together directly exported 4.3\% of supplied timber [63].

All Slovak forest owners are entitled to manage their forests in accordance with the respective legal provisions of the Forest Act [64]. Regardless of the area of forest land, they are obliged to manage their forests according to obligatory forest management plans in terms of allowable cut and stand reforestation requirements. Moreover, they must ensure the proper management of their forests by the authorized professional foresters with required education and experience in order to manage all forests in a sustainable way. The control of their forestry practice is performed through a system of state administration bodies. The real economic situation of forest owners is very different and depends mostly on the real size of their forest property. It shall be noted that there are almost 9 thousand forest owners in Slovakia whose forest holding areas range from less than one hectare to several tens of thousands of hectares. The largest state forest enterprise manages the structure of regional forest enterprises and their subordinate units, called forest districts, manage almost 0.9 million ha of forest land (on average, 7000 ha per forest district). Concerning forest certification decisions, these are taken at the level of regional forest enterprises, whereas the fulfilment of certification criteria is audited at the forest district level. On the other hand, the average area of non-state forest owners is approximately 200 ha; the smallest private forest owners managing their forests by themselves have, on average, $30-40$ ha of forest land; the largest forest land associations have $4500-5000$ ha; and the largest municipal forests, between 15,000-20,000 ha [65].

State forest enterprises (and also the largest non-state forest owners) perform their activities effectively in favourable conditions benefiting from timber trade business activities based on long-term contracts established with large industrial buyers [66]. By contrast, the management of non-state forest owners is, in many cases, economically ineffective as they suffer from a weak timber market position and high dependence upon services provided by contractors and a lack of highly qualified staff [67]. Some of these problems might be overcome by joint forest management in the form of forest owners' associations that shall serve as an instrument for supporting the sustainable management of non-state forests [68]. However, in Slovakia, such associations are disposed of low power due to their lack of communication [69], unwillingness to cooperate, disunity among their leaders, and ineffective management strategies [70].

\subsection{Objectives and Rationale for the Research}

The main objective of this study is to examine the general understanding of the certification concept as an environmental, economic and social tool and to determine incentives of forest owners in Slovakia for sustainable forest management certification.

This country-based study, for the first time, analyses in detail the forest owners' perception of certification in Slovakia-this country being an example of one of the countries in transition where the process of restitution of forest owner property rights started in the 1990s-together with the implementation of the concept of sustainable development. Thus, the economic and social environment 
of analysed phenomena shall be considered as completely different from those mentioned in similar studies conducted either in Western European countries or low-income developing countries.

In addition, this paper analyses the benefits and problems arising from participation of certified forest owners in certification and identifies the differences between the perception of national forest certification system, represented by the PEFC scheme, and forest management standard developed at the international level, represented by the FSC global standard implemented in Slovakia through a certification body program. Our study offers insights into the opinions of forest owners who are directly involved in the process of forest certification at the 'producer side'. Up until now, the majority of similar studies examined either the opinions and views of social tool final consumers of certified wood products or the $\mathrm{CoC}$ certificates holders.

\section{Materials and Methods}

The study was carried out using a mail questionnaire survey. Forest owners and managers selected for the survey were identified from the (i) national register of forest owners and managers [71], (ii) national PEFC database [72], and (iii) international FSC database [73] of sustainable forest management certificate holders. As the basis for determining the sample for the survey, the census of 8824 forest owners and managers registered in the national register was used. To determine the minimum sample size, we assumed a 5\% margin of error and a $95 \%$ confidence interval; thus giving the total number of 369 forest owners to be contacted in the survey. Survey development and implementation were based on the modified methods recommended by [74] including a pre-notification email and a first and second email to maximise the response rates. Data were collected from September to November 2017. In total, we contacted 400 forest owners for whom their email addresses were available, including all PEFC and FSC certified entities. A total of 273 responses were received, out of which 241 were correctly filled and suitable for analysis, thus, giving the adjusted return rate of $60.25 \%$ and margin of error of $6.23 \%$.

The questionnaire consisted of a cover letter explaining the content and eight sections. The first section contained questions regarding the profile of forest owners in terms of their forest area and ownership type. Six forest area size categories were provided, ranging from less than 100 ha to more than 50,000 ha. All legal forms of forest land ownership were defined: state, community, municipal, private, and church forests. According to the certification scheme used, the forest owners were classified as PEFC, FSC, or double (both PEFC and FSC) certificate holders. The following content of the questionnaire was based on the findings of previous international research presented in the introduction chapter of this study on the role and the understanding, perception, and impact of SFM certification. The second section of the questionnaire contained questions aimed at the examination of all forest owners' (certified and non-certified) level of understanding the forest certification concept both based on the objectives of PEFC and FSC certification as well as to determine the level of agreement with the basic certification statements. The researchers provided definitions of forest certification concepts to assure a consistent frame of reference for the respondents. The main certification statements referred to the main objectives and purposes of forest certification regarding the promotion of sustainable forest management and the use of sustainable resources, commitment to environmental responsibility, improvement of forest owners' image, legality issues, market access, profit margin, improved communication, as well as the improvement of the internal efficiency of management. In the third section only the certified participants were asked to provide internal information on their involvement in the certification process, namely the expectations motivating forest owners to implement certification such as the improvement of forest management and demonstration of sustainable forestry practices, internal economic performance factors linked to the increase in sales and profit, market performance factors related to finding new customers, and other factors such as commitment to environmental issues and the improvement of the company image. Similar factors were defined to allow forest owners to identify the main benefits following from the adoption of certification requirements. In addition, questions linked to the difficulties regarding certification and related costs of 
implementation of certification standards were included. Particular questions were formulated on the basis of the main responsibilities for forest owners defined by certification standards. They were aimed to identify difficulties regarding different administrative issues linked to documentation, internal and external audits, ensuring compliance with certification criteria by contractors, implementation of preventive and corrective measures, training and personnel requirements, communication, and costs. Cost-related questions aimed to identify the perception of cost linked to the certification system implementation and maintenance, cost of external and internal audits, and cost induced by changes in forest management practices. The final section of the questionnaire was oriented to the issue of the price premium received by forest owners for selling their certified wood.

A five-point Likert scale was used to measure the level of understanding of the certification concepts and level of agreement with principal certification statements, where 1 corresponded to 'strongly disagree' or 'do not understand not at all', the mid-point 3 was 'neither disagree nor agree' or 'somewhat understand' (a neutral mid-point), and 5 was 'strongly agree' or 'completely understand'. The same approach was used to evaluate the level of problem severity the forest owners face. The reliability of factors regarding the agreement of forest owners with the main objectives and purposes of forest certification, expectations that motivated them to enter the certification process, as well as related benefits and difficulties, was tested by using Cronbach's alpha coefficient. A reliability coefficient of 0.7 and above was considered and acceptable for the consistency level [75].

Data were analysed using the statistical analysis software SPSS. The non-parametric Mann-Whitney U test was used to determine the differences in the distribution of categorical variables. In particular, differences were identified between the certified and non-certified forest owners as well as between the different ownership categories and holders of certificates of different certification schemes. For these purposes, all ownership categories were grouped into two main categories: state and non-state forest owners. In order to determine the influence of the certification scheme on the responses, the certified forest owners were divided into two groups (PEFC and FSC). Additionally, we used a chi-square test to identify all the group distributions and to highlight differences between respondents of different forest areas. To eliminate the number of forest area size categories and thus eliminate the occurrence of empty cells in the analysis, three main categories were created: small (up to 500 ha), medium (501-10,000 ha), and large (more than 10,000 ha).

\section{Results}

The survey compares the attitudes towards forest certification of certified and non-certified forest owners in Slovakia. A share of certified forest area (63.4\%) reflects the present situation in Slovakia where all state companies managing more than $53 \%$ of forest land have implemented some of the existing certification systems. In total, $69 \%$ of respondents were using one of the two certification systems, namely FSC and PEFC. The share of PEFC certificate holders was $92 \%$ and FSC, $4 \%$. Additionally, $4 \%$ of responding companies were double certified (Figure 1 ).

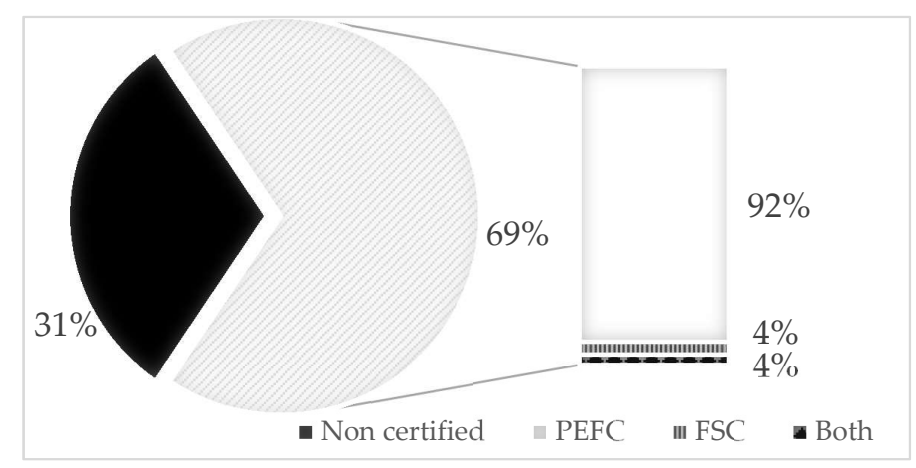

Figure 1. The structure of respondents by certification scheme implemented. 
Data were collected among forest owners of all types of ownership. Respondents were mostly represented by the community type of ownership (38\%), followed by the state forests (24\%), municipal forests, and different private forest owners (18\% each) (Figure 2). For the purposes of further analysis, ownership types were grouped into two main categories: state $(24 \%)$ and non-state forest ownership (76\%).

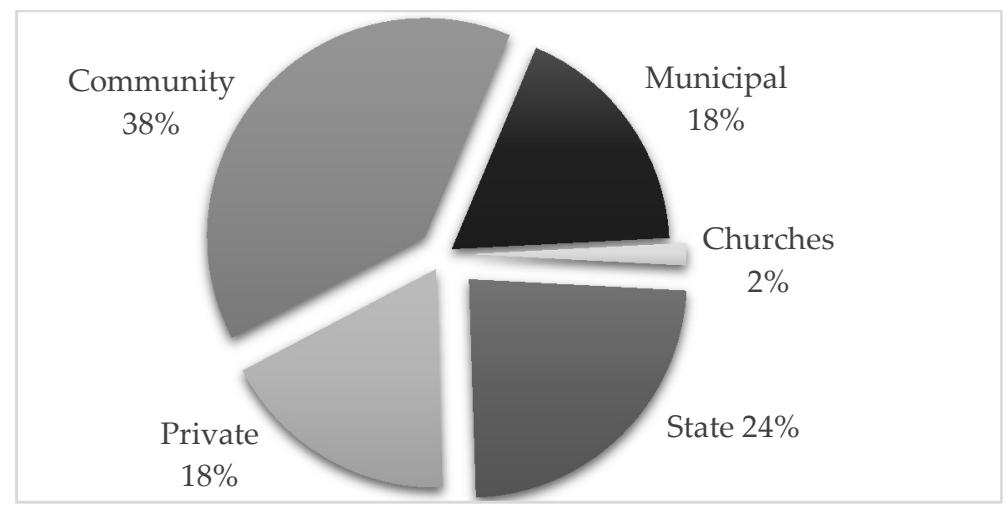

Figure 2. The structure of respondents by ownership.

The area of managed forests was used as an indicator of company size. Figure 3 shows that small owners (up to $500 \mathrm{ha}$ ) represent $35 \%$ of the respondents, followed by medium-size (501-10,000 ha) owners (55\%). Only $10 \%$ of respondents represented large owners managing more than 10,000 ha of forests.

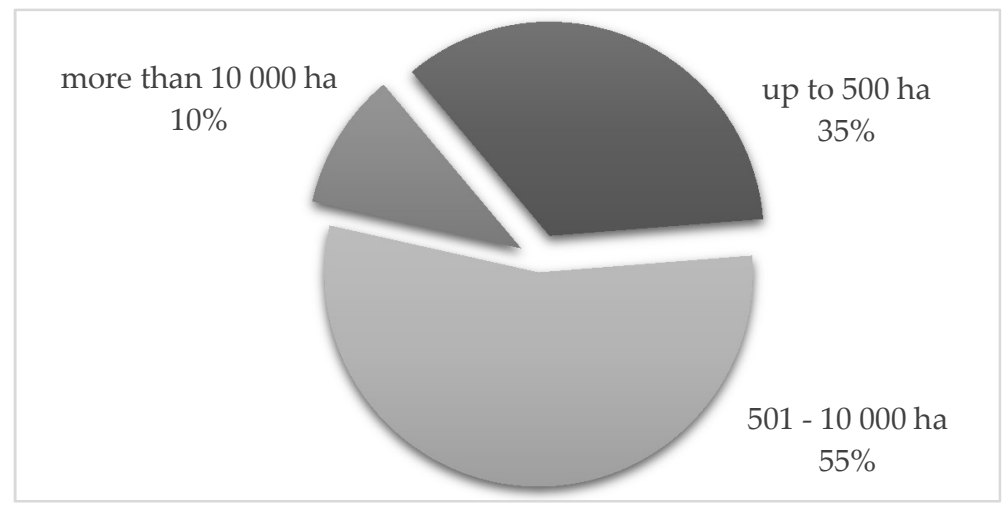

Figure 3. The structure of respondents by company size.

All group distributions were tested for differences between the ownership, forest area, and certification scheme. Using the chi-square test, there were significant differences identified between the individual types of ownership $\left(\chi^{2}=33.731, p=0.000\right)$ and company size $\left(\chi^{2}=99.001, p=0.000\right)$, however, no significant differences were seen among users of individual certification schemes.

Table 1 shows the forest owners' level of understanding of the certification concepts and agreement with basic certification statements. The reliability of examined factors using Cronbach's alpha coefficient was 0.867 . With the highest mean score of 4.11 , the respondents demonstrated an understanding of the concept of sustainable forest management; however, the differences between the certified (4.35) and non-certified owners (3.57) were significant. This was followed by the understanding of PEFC objectives (3.76) and FCS objectives (3.12). Naturally, certified owners understand objectives of both certification schemes significantly better than non-certified ones. 
Respondents strongly believe that certification represents a commitment to environmental responsibility (4.03) and, at the same time, it improves the external company image (4.02). These issues were closely followed by sustainability-related issues, namely, the promotion of sustainable utilisation of forest resources (3.90) and the improvement of forest management practices (3.61). Certification is also seen as a tool to improve market access (3.27).

Respondents expressed the lowest level of agreement with the statements regarding the economic issues and those related to the improvement of the internal efficiency that forest certification may bring to companies. These include increasing profit margins (2.87) and the improvement of management efficiency (3.01).

Table 1. The forest owners' level of understanding of certification concepts and agreement with basic certification statements.

\begin{tabular}{|c|c|c|c|c|c|}
\hline $\begin{array}{l}\text { Understanding of ... } \\
\qquad n=241\end{array}$ & Mean & $\begin{array}{c}\text { Mean } \\
\text { Certified } \\
\text { Companies }\end{array}$ & $\begin{array}{c}\text { Mean } \\
\text { Non-Certified } \\
\text { Companies }\end{array}$ & $\begin{array}{c}\text { Standard } \\
\text { Deviation } \\
\text { (SD) }\end{array}$ & $\begin{array}{c}\text { Mann- } \\
\text { Whitney } \\
\text { U Test }\end{array}$ \\
\hline Sustainable forest management (SFM) concept & 4.11 & 4.35 & 3.57 & 1.051 & $3829.0 *$ \\
\hline $\begin{array}{l}\text { Programme for the Endorsement of Forest Certification } \\
\text { (PEFC) objectives }\end{array}$ & 3.76 & 4.13 & 2.96 & 1.186 & $3064.5 *$ \\
\hline Forest Stewardship Council (FSC) objectives & 3.12 & 3.30 & 2.73 & 1.175 & $4616.0 *$ \\
\hline \multicolumn{6}{|l|}{$\begin{array}{c}\text { Certification ... } \\
n=241\end{array}$} \\
\hline Represents a commitment to environmental responsibility & 4.03 & 4.21 & 3.64 & 1.036 & $4303.0 *$ \\
\hline Improves external company image & 4.02 & 4.19 & 3.65 & 1.076 & 4477.0 * \\
\hline Promotes sustainable utilisation of forest resources & 3.90 & 4.13 & 3.39 & 1.092 & $3792.5 *$ \\
\hline Improves forest management practices & 3.61 & 3.74 & 3.32 & 1.113 & $4893.0 *$ \\
\hline Improves market access & 3.27 & 3.37 & 3.03 & 1.206 & $5248.0 *$ \\
\hline Improves communication with customers & 3.16 & 3.20 & 3.05 & 1.088 & 5779.5 \\
\hline Prevents from illegal logging & 3.05 & 3.11 & 2.92 & 1.295 & 5622.0 \\
\hline Improves management efficiency & 3.01 & 3.08 & 2.85 & 1.019 & 5427.5 \\
\hline Increases profit margins & 2.87 & 2.81 & 3.00 & 1.185 & 5595.5 \\
\hline
\end{tabular}

Scale of agreement: (1 strongly disagree, 3 neither disagree nor agree, 5 strongly agree). ${ }^{*} p<0.05$.

Using the Mann-Whitney U test, a significant difference in levels of agreement with certification statements between the certified and non-certified companies was found at a 0.05 level of significance. The results show that there are significant differences between certified and non-certified companies in all five top-ranked statements described above. The statements dealing with environmental responsibility, company image, and forest resource management were identified by certified respondents as the most suitable to explain the role of forest certification. The certified status of forest owners is not important when considering the role of certification as a tool that can increase profit margins $(U=5595.5, p=0.191)$, improve management efficiency $(U=5427.5, p=0.089)$, prevent illegal logging ( $\mathrm{U}=5622.0, p=0.215)$, or improve communication with customers $(\mathrm{U}=5779.5, p=0.353)$.

To explore what the main expectations were that motivated certified companies to obtain forest certification, owners were provided several options covering a range of the most important benefits and problems the certification may bring. The reliability of examined factors using Cronbach's alpha coefficient was 0.839 . The most important motive was the improvement of external company image (mean score 4.30). Other expectations motivating owners to be certified were linked to the demonstration of sustainable forest management practices (4.23), commitment to environmental issues (4.14), improvement of forest management (3.57), and the search to obtain new customers (3.03). Other issues, such ambitions to increase profit margins (2.73) or to increase sales volume (2.68) were considered as the least motivating factors (Table 2). It follows that forest certification is considered by certified forest owners as a tool that can improve their external image and help to demonstrate their management practices through their environmental commitments. A non-parametric test (Mann-Whitney U test) was used to prove the significant difference in the levels of agreement with certification motives between the certification schemes and ownership types at a 0.05 level of significance. The test confirmed that the difference between forest owners certified by different 
certification schemes was significant only for one factor focused on the demonstration of sustainable forest management practices $(\mathrm{U}=162.0, p=0.001)$, where the PEFC certificate holders are more convinced than FSC ones that forest certification can be a suitable tool to promote their sustainable management practices.

Table 2. The level of agreement of certified forest owners with main expectations following from the implementation of certification.

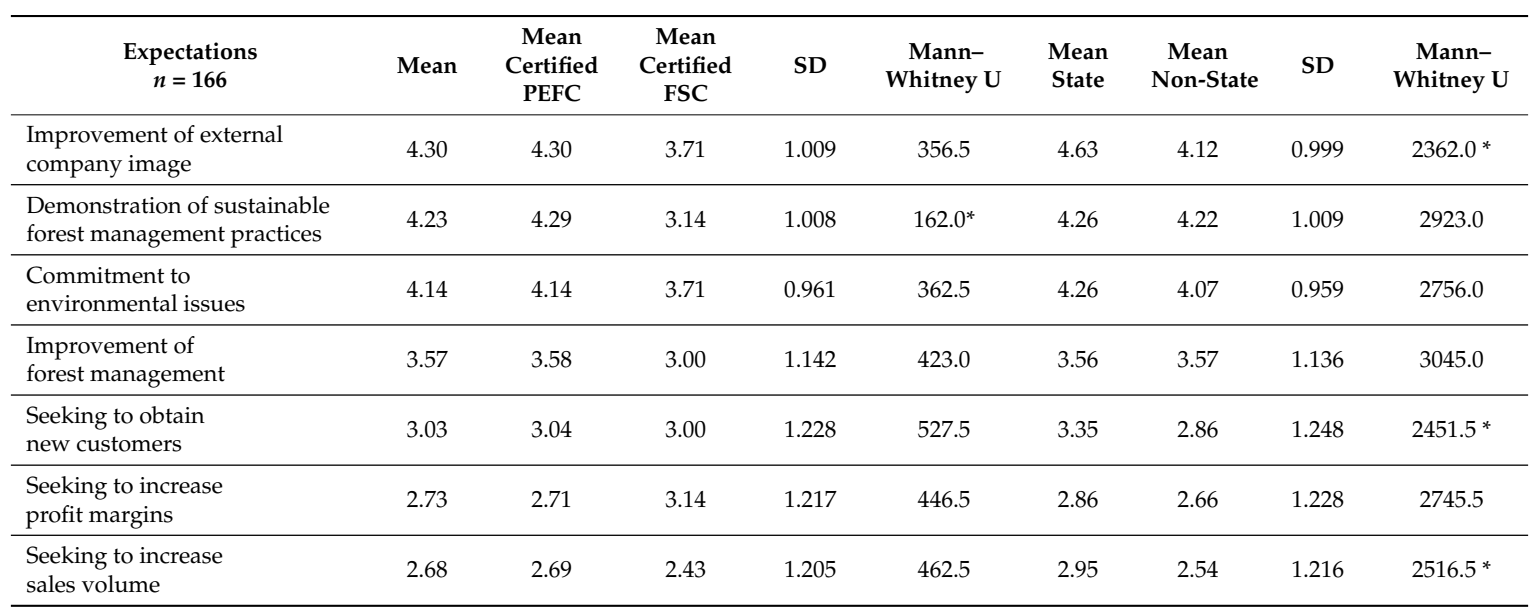

Scale of agreement: (1 strongly disagree, 3 neither disagree nor agree, 5 strongly agree). ${ }^{*} p<0.05$.

Similarly, using the chi-square test, there was a significant difference identified between the forest owners of different company sizes where almost $85 \%$ of medium-sized forest owners and $65 \%$ of large owners consider the demonstration of sustainable forest management practices $\left(\chi^{2}=29.525, p=0.000\right)$ as very significant. On the other side, small owners had mostly indifferent answers. Statistically significant differences in expectations between the state and non-state forest sector can be found in three cases (the state owners being the ones with more recognised motivation for certification): seeking to increase sales volume $(U=2516.5, p=0.037)$ and obtain new customers $(U=2451.5, p=0.021)$, as well as the improvement of the external company image $(\mathrm{U}=2362.0, p=0.004)$.

The motivation for the introduction of certification is directly linked to the benefits it brings. Respondents consider the possibility to demonstrate forest management practices (3.61) and the better understanding of forest management concept (3.50) to be the most important benefits.

Considering the effect of the certification scheme, the Mann-Whitney U test proved the significant differences in levels of agreement with the main benefits of certification for certified entities (Table 3). The differences were recorded in terms of improvement of forest management practices $(U=310.0$, $p=0.049)$, increase of sales volume $(\mathrm{U}=299.0, p=0.040)$, management efficiency and record keeping $(\mathrm{U}=298.5, p=0.039)$, as well as the understanding of forest management concepts $(\mathrm{U}=256.5, p=0.016)$, and the possibility of demonstrating forest management practices $(U=245.0, p=0.011)$. Considering these issues, PEFC-certified companies are more identified with the aforementioned benefits of forest certification than the FSC certified companies.

There were also significant differences in benefits identified between the different types of ownership. Namely, state forest owners rather than non-state benefit from the penetration of new markets $(\mathrm{U}=2422.5, p=0.017)$ and improvement of communication with customers $(\mathrm{U}=2500.5$, $p=0.033$ ). Differences between the main benefits of certification in terms of the forest area were identified in the case of two different factors focused on the penetration of new markets $\left(\chi^{2}=18.313\right.$, $p=0.019)$ and the possibility to demonstrate forest management practices $\left(\chi^{2}=17.722, p=0.023\right)$. Small and medium-size forest owners consider these benefits less significant, while large forest owners consider them as important issues. 
Table 3. The levels of agreement of certified forest owners with the main certification benefits.

\begin{tabular}{|c|c|c|c|c|c|c|c|c|c|}
\hline $\begin{array}{c}\text { Benefits } \\
n=166\end{array}$ & Mean & $\begin{array}{l}\text { Mean } \\
\text { Certified } \\
\text { PEFC }\end{array}$ & $\begin{array}{l}\text { Mean } \\
\text { Certified } \\
\text { FSC }\end{array}$ & SD & $\begin{array}{c}\text { Mann- } \\
\text { Whitney U }\end{array}$ & $\begin{array}{c}\text { Mean } \\
\text { State }\end{array}$ & $\begin{array}{l}\text { Mean } \\
\text { Non-State }\end{array}$ & SD & $\begin{array}{c}\text { Mann- } \\
\text { Whitney U }\end{array}$ \\
\hline $\begin{array}{l}\text { Possibility to demonstrate forest } \\
\text { management practices }\end{array}$ & 3.61 & 3.63 & 2.57 & 1.072 & 245.0 * & 3.79 & 3.52 & 1.077 & 2792.5 \\
\hline $\begin{array}{l}\text { Better understanding of forest } \\
\text { management concept }\end{array}$ & 3.50 & 3.56 & 2.29 & 1.133 & $256.5^{*}$ & 3.40 & 3.55 & 1.143 & 2815.5 \\
\hline $\begin{array}{l}\text { Improvement of } \\
\text { management efficiency }\end{array}$ & 3.09 & 3.14 & 2.14 & 1.098 & $298.5^{*}$ & 3.19 & 3.04 & 1.116 & 2860.0 \\
\hline $\begin{array}{l}\text { Improvement of } \\
\text { communication with customers }\end{array}$ & 2.92 & 2.96 & 2.29 & 1.224 & 370.5 & 3.19 & 2.78 & 1.226 & 2500.5 * \\
\hline
\end{tabular}

Scale of agreement: (1 strongly disagree, 3 neither disagree nor agree, 5 strongly agree). ${ }^{*} p<0.05$

In addition to the survey of certification stimulus and expected benefits, we also focused on the perceived level of problems related to forest certification. Several main problematic areas were defined for respondents (Table 4). Generally, the perceived level of problems related to certification issues is considered to be not very problematic (the score of answers ranges from 1.85 to 2.60 ) in comparison to perceived expectations (2.68-4.30) and benefits (2.54-3.61).

Table 4. The level of agreement of certified forest owners with the main problems related to certification.

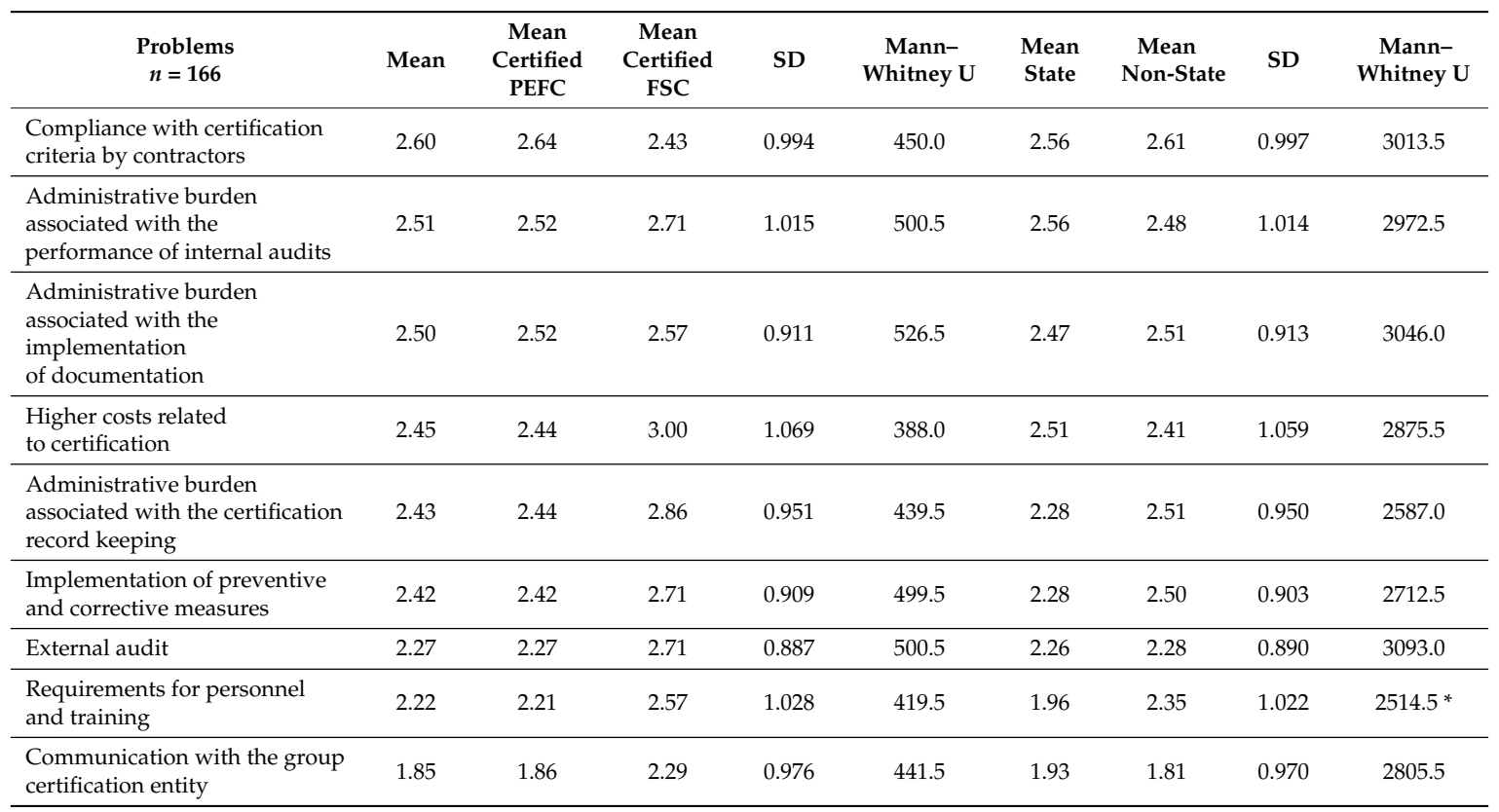

Scale of agreement: (1 strongly disagree, 3 neither disagree nor agree, 5 strongly agree). ${ }^{*} p<0.05$.

Compliance with the certification criteria by contractors (mean score 2.60) is considered to be the most important difficulty for the forest owners, followed by a range of problems related to the administrative burden associated with the performance of internal audits (2.51) and with the implementation of documentation (2.50). Other certification related issues, for example, external audit, personnel and training, or communication with the group entity seems to be perceived as less problematic. It is noteworthy that there were no differences identified in terms of the certification scheme and ownership type except perceiving a higher level of problems related to the requirements 
for personnel and training by non-state owners $(U=2514.0, p=0.036)$ and small owners $\left(\chi^{2}=16.869\right.$, $p=0.032$ ).

Even if the costs were not perceived as the most important problem related to certification (rated 2.45), we have further explored how certified entities perceive different types of certification costs (Table 5). Costs are mainly connected to certification system implementation and maintenance (2.95) and external audits (2.91), followed by costs related to changes in forest management practices (2.81) and internal audits (2.75). FSC-certified companies consider the costs of external audits and certificate issuance significantly higher that PEFC-certified companies $(U=340.0, p=0.048)$. There were no differences recorded between different ownership types or the size of the forest area.

Table 5. The evaluation of certification cost level by certified forest owners.

\begin{tabular}{|c|c|c|c|c|c|c|c|c|c|}
\hline $\begin{array}{c}\text { Costs } \\
n=166\end{array}$ & Mean & $\begin{array}{l}\text { Mean } \\
\text { Certified } \\
\text { PEFC }\end{array}$ & $\begin{array}{c}\text { Mean } \\
\text { Certified } \\
\text { FSC }\end{array}$ & SD & $\begin{array}{c}\text { Mann- } \\
\text { Whitney U }\end{array}$ & $\begin{array}{c}\text { Mean } \\
\text { State }\end{array}$ & $\begin{array}{l}\text { Mean } \\
\text { Non-State }\end{array}$ & SD & $\begin{array}{c}\text { Mann- } \\
\text { Whitney U }\end{array}$ \\
\hline $\begin{array}{l}\text { System implementation } \\
\text { and maintenance }\end{array}$ & 2.95 & 2.95 & 3.29 & 0.857 & 357.5 & 3.04 & 2.91 & 0.859 & 3023.5 \\
\hline $\begin{array}{l}\text { External audit and } \\
\text { certificate issuance }\end{array}$ & 2.91 & 2.90 & 3.29 & 0.785 & 340.0 * & 2.89 & 2.92 & 0.785 & 2955.5 \\
\hline $\begin{array}{l}\text { Internal audit and } \\
\text { related controls }\end{array}$ & 2.75 & 2.74 & 3.14 & 0.830 & 362.0 & 2.75 & 2.74 & 0.829 & 3008.5 \\
\hline
\end{tabular}

Scale of agreement: (1 low, 3 appropriate, 5 high). ${ }^{*} p<0.05$.

An increase in the total costs related to certification should be outweighed by the green premium obtained from the sale of certified wood. In particular, the respondents were asked about the price premium they receive for the certified wood they sell. Almost $74 \%$ of respondents replied that they may obtain an extra price premium of $1-5 \%$, and $9 \%$ of respondents mentioned a price premium of $6-10 \%$ for their certified wood compared to non-certified wood. On the other hand, $12.7 \%$ of forest owners do not receive any price premium. (Figure 4).

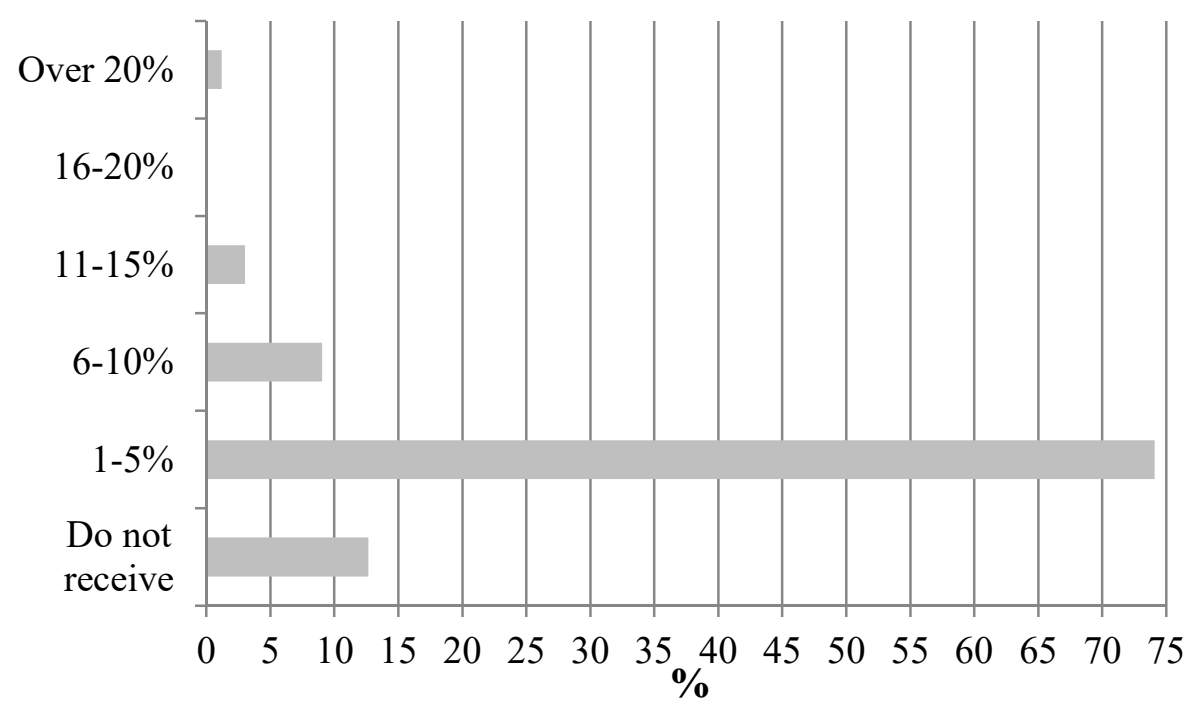

Figure 4. The green premium received by forest owners for selling certified wood.

\section{Discussion}

Considering the significant differences in the understanding of the concept of sustainable forest management between the certified and non-certified forest owners, it should be noted that the certified owners are certainly disposed to a better knowledge of such concept-in accordance with the 
perception of certification as a tool for the promotion of SFM [5-7]. In the case of PEFC-certified forest owners, the understanding of PEFC objectives was significantly higher compared to FSC certificate holders and the FSC scheme. This might be because of the national approach by PEFC that results in improved communication and proximity to forest owners, as well as due to the system of compulsory regular training provided for certified owners by the Slovak PEFC governing body [76]. This is also in line with [10], according to which the certification shall serve as a tool supporting the development and use of forest management procedures accepted generally by all participating stakeholders.

The research shows that the certified owners, by contrast with the non-certified ones, are strongly convinced that certification is a way in which to improve their external image which is built upon their commitments to environmental responsibility. Thus, the certified owners in particular understand certification as a tool for presenting their improved forest management practices and, consequently, developing their environmental performance $[24,34,35,37,41,42,44,45]$. On the other hand, neither the certified nor non-certified forest owners consider the economic role of certification to be an important one. Both groups of forest owners assign substantially lower ratings to statements connected to their economic performance, unlike views of Nakamura et al. [25], Rickenbach and Overdevest [16], Takahashi [26], and Van Kooten et al. [21]. These results approve the views of certification as a soft policy instrument $[12,13]$.

To discuss the differences between the PEFC certified forest owners and FSC certified ones, the following comments shall be kept in mind. Reflecting the expectations that motivated certified companies to obtain forest certification, the PEFC certified forest owners rated all but one expectation at the higher level than the FSC certified ones (the one exception being the expectation to increase profit margin). This may relate to the "FSC only policy" of large companies in CoC who seek to control their wood supply chains. Moreover, PEFC-certified owners more significantly expected forest certification to be a suitable tool to promote their sustainable management practices.

Certified forest owners consider the possibility to demonstrate forest management practices as the main benefit following from certification. In general, the PEFC certified forest owners perceived the benefits of certification much better than the FSC certified ones, except for the economic benefits connected to market penetration, increased sales volume, and potential price premium. It is important to note that statistical differences were found in the "non-economic" cases. On the other hand, differences between answers that focused on benefits with economic character were not statistically significant.

Ensuring compliance of contractors with certification requirements and administrative burden associated with the performance of internal audits and the implementation of documentation were identified as the main problems by the respondents. Similar problems connected with certification were mentioned by Giessen et al. [77] and Paluš et al. [34]. By examining the perceived level of problems related to certification issues, it was revealed that FSC-certified forest owners perceived almost all problems more seriously than PEFC certified ones who only consider the compliance with certification criteria by contractors as a more problematic issue. However, no significant differences between the two schemes were identified.

Furthermore, the ownership and forest sizes of owners are also significant factors influencing the perception of certification expectations, benefits, and problems. Higher expectations were identified by the state forest owners, especially those related to obtaining new customers and increasing sales volume. These expectations may follow from their rather large-scale timber trade business activities [51]. The same situation arises when the main certification benefits, especially those related to the new market penetration of the state forest sector. As the state forest sector operates through rather large forest enterprises with their area well over 10,000 ha [65], these results are further confirmed by the fact that large forest owners consider benefits connected to the new market penetration as significantly important issues, unlike small and medium-size ones.

On the other hand, there are no statistically significant differences in the perception of the main problems related to certification between the state and non-state forest sectors, except for personnel 
capacities. In this case, the problems of non-state owners are significantly higher in comparison with the state ones-such problems being the result of the general lack of skilled staff and unwillingness of small forest owners to cooperate [70]. Regardless of the ownership type, the problematic compliance with the certification criteria by contractors shall be perceived as a typical problem in the case of Slovak forestry where all forest owners are highly dependent upon the services provided by contractors $[67,78]$. However, it shall be noted that, according to PEFC Slovakia [79], it is the forest owner who is responsible for ensuring such compliance.

Finally, it is worth mentioning that all perceived expectations and benefits scored at a higher average value on a five-point scale compared to the perceived problems. This implies that the positive aspects of certification are generally more valued than its shortcomings. Similar findings can be found, for example, in Paluš et al. [34,35].

Although several authors recognize costs of certification as one of the obstacles to certification implementation $[11,43,52-54]$, costs were not perceived as an important issue by respondents in this research, regardless of their size or ownership type. Finally, considering the price premium obtained from the sale of certified wood that outweighs the possible certification costs, the most frequently identified premium of $1-5 \%$ corresponds to an adequate level of price premium in the certified supply chain identified by, for example, Owari and Sawanobori [44] and Paluš et al. [34,35].

Most of the findings indicate that once the national certification system represented by PEFC endorsed SFCS is considered, there is a better awareness and understanding of the objectives, concept, and benefits following from the forest certification. A national system developed under the "bottom-up" principle, respecting national legislation and traditions, reflecting local specifics and conditions, and thus giving local stakeholders possibilities to shape the system requirements, is more effective in the effort to increase the value of certification as a tool promoting wider debates and dialogs and, subsequently, in promoting sustainable forestry practices among forest owners. A better understanding of the entire potential of forest certification context facilitates forest owners and managers to implement certification requirements and reinforces the recognition of the role of certification as a tool supporting forestry policy objectives.

This research highlighted differences in the perception of the role and objectives of two certification systems that were developed and implemented in a specific country under different regimes. The findings of this study can serve as a basis for assessing similar relationships in other countries where certification schemes are implemented on the same principles.

\section{Conclusions}

The study was aimed at examining the general understanding of forest certification as environmental, economic, and social tools by forest owners in Slovakia and, in particular, their main expectations, benefits, and problems arising from participation in the certification process. Specifically, attention was paid to identifying differences reflecting the ownership structure of forests, the size of the forest area, and forest owners' participation in a particular certification programme implemented in Slovakia. The following conclusions can be drawn:

- certified forest owners are disposed of better knowledge of the sustainable forest management concept compared to non-certified ones. At the same time, certified entities have a better understanding of the PEFC objectives than the FSC objectives;

- certified forest owners, unlike non-certified, consider certification to be a tool representing a commitment to environmental responsibility that improves external company image, promotes sustainable utilisation of forest resources, and improves forest management practices;

- regardless of the certified status, forest owners have a neutral attitude towards certification as a tool for improving communication with customers, preventing illegal logging, and improving management efficiency, and at the least associate certification with its role helping to increase profit margins; 
- certificate holders are mainly expected from certification to improve their external image (primarily state forests), help to demonstrate SFM practices (primarily those of PEFC certified), and enable them to commit to environmental issues;

- certified forest owners considered the possibility of demonstrating forest management practices as the main benefit following from certification;

- $\quad$ PEFC certified forest owners perceived the benefits of certification considerably better than the FSC certified ones, except for the economic benefits such as market penetration, increased sales volume, or potential price premium;

- regardless of the size or certification scheme used, the main certification problems are those related to ensuring compliance with the certification criteria by contractors and administrative difficulties associated with the implementation of documentation and the performance of internal audits;

- in general, positive aspects of certification are better valued by forest owners than its shortcomings;

- certification costs are not considered to be the main problem in contrast to the system implementation and its maintenance as well as external audit performance;

- the majority of certified forest owners receive a green price premium of up to $5 \%$ for the sale of certified timber;

- roles of certification in the framework of forest policy, in particular those related to the promotion of sustainable forest management, improved stakeholder participation, and support for forest policy objectives, are better recognised within the PEFC endorsed national certification scheme than the FSC international one.

Author Contributions: H.P., J.P., and J.Š. prepared the literature review and elaborated chapters Materials and Methods, Results, Discussion, and Conclusions. R.Š. and J.L. organized the survey, collected data and worked on chapters Results and Discussion.

Funding: This work was supported by the VEGA No. 1/0473/16, VEGA No. 1/0688/16, APVV-15-0715, APVV-14-0869.

Acknowledgments: The authors are grateful for the support of the Scientific Grant Agency of the Ministry of Education, Science, Research and Sport of the Slovak Republic, and the Slovak Academy of Sciences, VEGA No. 1/0473/16, "Dynamics and determinants of wood-based products market in the Slovak Republic", VEGA No. 1/0688/16 "Economic and legal conditions of sustainable public access to forests", the Slovak Research and Development Agency, APVV-14-0869 "Research of the utilization of wood as a renewable raw material in the context of a green economy" and APVV-15-0715 "Implementation and evaluation analysis of forest policy instruments".

Conflicts of Interest: The authors declare no conflict of interest.

\section{References}

1. Machar, I. Attempt to summarize the problems: Is a sustainable management of floodplain forest geobiocenoses possible? In Biodiversity and Target Management of Floodplain Forests in the Morava River Basin (Czech Republic); Univerzita Palackého: Olomouc, Czech, 2010; pp. 189-226, ISBN 978-80-244-2530-6.

2. WCED. Report of the World Commission on Environment and Development: Our Common Future Acronyms and Note on Terminology Chairman's Foreword; Oxford University Press: Oxford, UK, 1987.

3. UNCED Non-Legally Binding Authoritative Statement of Principles for a Global Consensus on the Management, Conservation and Sustainable Development of All Types of Forests. Available online: http://www.un.org/documents/ga/conf151/aconf15126-3annex3.htm (accessed on 9 July 2017).

4. Rametsteiner, E.; Simula, M. Forest certification-An instrument to promote sustainable forest management? J. Environ. Manag. 2003, 67, 87-98. [CrossRef]

5. Durst, P.B.; Mckenzie, P.J.; Brown, C.L.; Appanah, S. Challenges facing certification and eco-labelling of forest products in developing countries. Int. For. Rev. 2006, 8, 193-200. [CrossRef]

6. Perera, P.; Vlosky, P.R.; Hughes, G.; Dunn, M.A. What do Louisiana and Mississippi Nonindustrial Private Forest Landowners Thing about Forest Certification? South. J. Appl. For. 2007, 31, 170-175.

7. Siry, J.P.; Cubbage, F.W.; Ahmed, M.R. Sustainable forest management: Global trends and opportunities. For. Policy Econ. 2005, 7, 551-561. [CrossRef] 
8. Auld, G.; Gulbrandsen, L.H.; McDermott, C.L. Certification Schemes and the Impacts on Forests and Forestry. Annu. Rev. Environ. Resour. 2008, 33, 187-211. [CrossRef]

9. Lewis, R.A.; Davis, S.R. Forest certification, institutional capacity, and learning: An analysis of the impacts of the Malaysian Timber Certification Scheme. For. Policy Econ. 2015, 52, 18-26. [CrossRef]

10. MacDicken, K.G.; Sola, P.; Hall, J.E.; Sabogal, C.; Tadoum, M.; de Wasseige, C. Global progress toward sustainable forest management. For. Ecol. Manag. 2015, 352, 47-56. [CrossRef]

11. Moore, S.E.; Cubbage, F.; Eicheldinger, C. Impacts of Forest Stewardship Council (FSC) and Sustainable Forestry Initiative (SFI) Forest Certification in North America. J. For. 2012, 110, 79-88. [CrossRef]

12. Nussbaum, R.; Simula, M. The Forest Certification Handbook; Garforth, M., Mayers, J., Eds.; Earthscan: London, UK, 2005; ISBN 1844071235.

13. Šálka, J.; Dobšinská, Z.; Sarvasova, Z.; Štěrbová, M.; Paluš, H. Lesnícka politika (Forest Policy); Technical University in Zvolen: Zvolen, Slovakia, 2017; ISBN 978-80-228-3008-9.

14. Cabarle, B.; Hrubes, R.J.; Elliot, C.; Synnott, T. Certification Accreditation: The Need for Credible Claims. J. For. 1995, 93, 12-16. [CrossRef]

15. Johnson, D.; Walck, C. Certified Success: Integrating Sustainability into Corporate Management Systems. J. For. 2004, 102, 32-39. [CrossRef]

16. Rickenbach, M.; Overdevest, C. More than Markets: Assessing Forest Stewardship Council (FSC) Certification as a Policy Tool. J. For. 2006, 104, 143-147. [CrossRef]

17. Rametsteiner, E.; Pülzl, H.; Alkan-Olsson, J.; Frederiksen, P. Sustainability indicator development-science or political negotiation? Ecol. Indic. 2011, 11, 61-70. [CrossRef]

18. FAO UN 15.2.1 Sustainable Forest Management | Sustainable Development Goals I Food and Agriculture Organization of the United Nations. Available online: http:/ / www.fao.org/sustainable-development-goals / indicators /1521/en (accessed on 25 June 2018).

19. Peck, T. The International Timber Trade; Woodhead Publishing Ltd.: Cambridge, UK, 2001; ISBN 9781855731905.

20. Ulybina, O.; Fennell, S. Analysis Forest certification in Russia: Challenges of institutional development. Ecol. Econ. 2013, 95, 178-187. [CrossRef]

21. Van Kooten, G.C.; Nelson, H.W.; Vertinsky, I. Certification of sustainable forest management practices: A global perspective on why countries certify. For. Policy Econ. 2005, 7, 857-867. [CrossRef]

22. Creamer, S.F.; Blatner, K.A.; Butler, B.J. Certification of family forests: What influences owners' awareness and participation? J. For. Econ. 2012, 18, 131-144. [CrossRef]

23. Tikina, A.; Kozak, R.; Larson, B. What factors influence obtaining forest certification in the U.S. Pacific Northwest? For. Policy Econ. 2008, 10, 240-247. [CrossRef]

24. Galati, A.; Gianguzzi, G.; Tinervia, S.; Crescimanno, M.; La Mela Veca, D.S. Motivations, adoption and impact of voluntary environmental certification in the Italian Forest based industry: The case of the FSC standard. For. Policy Econ. 2017, 83, 169-176. [CrossRef]

25. Nakamura, M.; Takahashi, T.; Vertinsky, I. Why Japanese firms choose to certify: A study of managerial responses to environmental issues. J. Environ. Econ. Manag. 2001, 42, 23-52. [CrossRef]

26. Takahashi, T. Why Firms Participate in Environmental Voluntary Initiatives: Case Studies in Japan and Canada; University of British Columbia: Vancouver, BC, Canada, 2001.

27. Stevens, J.; Ahmad, M.; Ruddell, S. Forest products certification: A survey of manufactures. For. Prod. J. 1998, 48, 43-49.

28. Owari, T.; Juslin, H.; Rummukainen, A.; Yoshimura, T. Strategies, functions and benefits of forest certification in wood products marketing: Perspectives of Finnish suppliers. For. Policy Econ. 2006, 9, 380-391. [CrossRef]

29. Aguilar, F.X.; Cai, Z. Conjoint effect of environmental labelling, disclosure of forest of origin and price on consumer preferences for wood products in the US and UK. Ecol. Econ. 2010, 70, 308-316. [CrossRef]

30. Aguilar, F.X.; Vlosky, R.P. Consumer willingness to pay price premiums for environmentally certified wood products in the U.S. For. Policy Econ. 2007, 9. [CrossRef]

31. Kozak, R.A.; Cohen, D.H.; Lerner, J.; Bull, G.Q. Western Canadian consumer attitudes toward certified value-added wood products: An exploratory assessment. For. Prod. J. 2004, 54, 21-24.

32. Ozanne, L.K.; Vlosky, R.P. Certification from the U.S. consumer perspective: A comparison from 1995 and 2000. For. Prod. J. 2003, 53, 13-21.

33. Ozanne, L.K.; Vlosky, R.P. Willingness to pay for environmentally certified wood products: A consumer perspective. For. Prod. J. 1997, 47, 39-48. 
34. Paluš, H.; Parobek, J.; Dudík, R.; Šupín, M. Assessment of chain-of-custody certification in the Czech and Slovak Republic. Sustainability 2017, 9, 1-13. [CrossRef]

35. Paluš, H.; Parobek, J.; Vlosky, R.P.; Motik, D.; Oblak, L.; Jošt, M.; Glavonjić, B.; Dudík, R.; Wanat, L. The status of chain-of-custody certification in the countries of Central and South Europe. Eur. J. Wood Wood Prod. 2018, 76, 699-710. [CrossRef]

36. Veisten, K. Willingness to pay for eco-labelled wood furniture: choice-based conjoint analysis versus open-ended contingent valuation. J. For. Econ. 2007, 13, 29-48. [CrossRef]

37. Vlosky, R.; Gazo, R.; Cassens, D.; Perera, P. Changes in value-added wood product manufacturer perceptions about certification in the United States from 2002 to 2008. Drv. Ind. 2009, 60, 89-94.

38. Vlosky, R.P.; Ozanne, L.K. Environmental certification of wood products: The U.S. manfacturers' perspective. For. Prod. J. 1998, 48, 21-26.

39. Yamamoto, Y.; Takeuchi, K.; Shinkuma, T. Is there a price premium for certified wood? Empirical evidence from log auction data in Japan. For. Policy Econ. 2014, 38, 168-172. [CrossRef]

40. WWF. The Forest Industry in the 21st Century. Report Prepared by the WWF's Forests for Life Campaign; Branksome House: Godalming, UK, 2000.

41. Perera, P.; Vlosky, R.P.; Dunn, M.A.; Hughes, G.U.S. home-center retailer attitudes, perceptions and behaviors regarding forest certification. For. Prod. J. 2008, 58, 21-25.

42. Mikulková, A.; Hájek, M.; Štěpánková, M.; Ševčík, M. Forest certification as a tool to support sustainable development in forest management. J. For. Sci. 2015, 61, 359-368. [CrossRef]

43. Paluš, H.; Kaputa, V. Survey of attitudes towards forest and chain of custody certification in the Slovak Republic. Drew. Wood 2009, 52, 65-81.

44. Owari, T.; Sawanobori, Y. Market Benefits of Chain of Custody Certification Perspectives of Japanese Suppliers. For. Resour. Manag. Math. Model. 2008, 7, 121-132.

45. Butterfield, R.P.; Hansen, E.; Fletcher, R.; Nikinmaa, H. Forest Certificaiton and Small Forest Enterprises: Key Trends and Impacts—Benefits and Barriers; Forest Trends: Washington, DC, USA, 2005; p. 59.

46. Hansen, E.; Punches, J. Developing Markets for Certified Forest Products: A Case Study of Collins Pine Company. For. Prod. J. 1999, 4, 30-35.

47. Hubbard, S.; Bowe, S. Putting Value on Certified Forest Products: Views from Wisconsin. Wood Wood Prod. 2004, 57-62.

48. EC. Regulation (EU) No 995/2010 of the European Parlament of the Councilof 20 October 2010 Laying Down the Obligations of Operators Who Place Timber and Timber Products on the Market; Official Journal of the European Union, EUR-Lex: Brussels, Belgium, 2010; pp. 23-34.

49. EFI. Support Study for Development of the Non-Legislative Acts Provided for in the Regulation of the European Parliament and of the Council Laying Down the Obligations of Operators Who Place Timber and Timber Products on the Market-Part 2: Options and Best p; European Forest Institute: Joensuu, Finland, 2011.

50. Cashore, B.; Stone, M.W. Can legality verification rescue global forest governance? Analyzing the potential of public and private policy intersection to ameliorate forest challenges in Southeast Asia. For. Policy Econ. 2012, 18, 13-22. [CrossRef]

51. Paluš, H. Trh a Obchod s Drevom a Výrobkami z Dreva (Wood and Wood Products Market and Trade); Technical University in Zvolen: Zvolen, Slovakia, 2013; ISBN 978-80-228-2587-0.

52. Carlsen, K.; Hansen, C.P.; Lund, J.F. Factors affecting certification uptake - Perspectives from the timber industry in Ghana. For. Policy Econ. 2012, 25, 83-92. [CrossRef]

53. Cubbage, F.; Diaz, D.; Yapura, P.; Dube, F. Impacts of forest management certification in Argentina and Chile. For. Policy Econ. 2010, 12, 497-504. [CrossRef]

54. Halalisan, A.F.; Marinchescu, M.; Popa, B.; Abrudan, I.V. Chain of Custody certification in Romania: Profile and perceptions of FSC certified companies. Int. For. Rev. 2013, 15, 305-314. [CrossRef]

55. Tian, N.; Lu, F.; Joshi, O.; Poudyal, N.C. Segmenting Landowners of Shandong, China Based on Their Attitudes towards Forest Certification. Forests 2018, 9, 1-14. [CrossRef]

56. Cubbage, F.W.; More, S.; Henderson, T.; Araujo, M.M.F.C. Costs and Benefits of Forest Certification in the Americas. In Natural Resources; Management, Economic Development and Protection; Paulding, J.B., Ed.; Nova Publishers: Hauppauge, NY, USA, 2009; ISBN 9781604569827.

57. Šupín, M. Forest and wood products certification influence on strategies for entering and developing international markets. Intercathedra 2006, 22, 166-169. 
58. Suchomel, J.; Gejdoš, M.; Tajboš, J. Analýza stavu a vývoja certifikácie lesov na Slovensku a v zahraničí. Lesn. Čas. For. J. 2011, 57, 208-215.

59. Paluš, H.; Mat'ová, H.; Križanová, A.; Parobek, J. A survey of awareness of forest certification schemes labels on wood and paper products. Acta Fac. Xylologiae 2014, 56, 129-138.

60. LESY SR LESY Slovenskej republiky (Forests of the Slovak Republic). Available online: www.lesy.sk (accessed on 2 March 2018).

61. FSC Facts and Figures. Available online: https://ic.fsc.org/en/facts-and-figures (accessed on 3 February 2018).

62. PEFC Slovakia PEFC Slovensko. Available online: https:/ / www.pefc.sk/ (accessed on 3 January 2018).

63. MPaRV SR. Report on the Forest Sector of the Slovak Republic 2016 Green Report; Ministry of Agriculture and Regional Development of the Slovak Republic; MPaRV SR, NLC: Bratislava, Slovak, 2017.

64. Národná rada Slovenskej Republiky Forest Act. Available online: http://www.zakonypreludi.sk/zz/2005326 (accessed on 23 June 2018).

65. Šulek, R.; Trenčiansky, M.; Giertliová, B. Forest property regimes in the Slovak Republic. In Forest and Sustainable Development; Abrudan, I.V., Spãrchez, G., Oprea, I., Simon, D., Ignea, G., Chitea, G., Eds.; Transilvania University of Brascedilla: Braşov, Romania, 2007; pp. 573-578.

66. Hajdúchová, I.; Giertliová, B.; Šulek, R. Specifics of forest enterprises' performance measurement. Austrian J. For. Sci. 2017, 134, 23-40.

67. Ambrušová, L.; Šulek, R. Factors influencing forest owners and manager's decision making about forestry services in logging-transport process / Faktory vplývajúce na rozhodnutia vlastníkov a obhospodarovatel'ov lesov o spôsobe zabezpečovania lesníckych služieb v t’ažbovo-dopravnom. For. J. 2014, 60, 177-184. [CrossRef]

68. Sarvašová, Z.; Zivojinovic, I.; Weiss, G.; Dobšinská, Z.; Drăgoi, M.; Gál, J.; Jarský, V.; Mizaraite, D.; Põllumäe, P.; Šálka, J.; Schiberna, E.; Šišák, L.; Wolfslehner, B.; Zalite, Z.; Zalitis, T. Forest Owners Associations in the Central and Eastern European Region. Small Scale For. 2015, 14, 217-232. [CrossRef]

69. Lichý, J. Proposal of model of forest enterprise media communication. Lesn. Čas. For. J. 2013, 59, $276-283$.

70. Šálka, J.; Dobšinská, Z.; Hricová, Z. Factors of political power-The example of forest owners associations in Slovakia. For. Policy Econ. 2016, 68, 88-98. [CrossRef]

71. NLC Register obhospodarovatel'ov (The Register of Forest Managers). Available online: https://gis.nlcsk. org/registre/Zoznamy/ZoznamOBH (accessed on 2 June 2017).

72. PEFC Certified/Certificates. Available online: https://www.pefc.org/find-certified/certified-certificates (accessed on 1 March 2017).

73. FSC Facts and Figures. Available online: https://ic.fsc.org/en/facts-and-figures (accessed on 5 February 2017).

74. Dillman, D.A. Mail and Internet Surveys: The Tailored Design Method; John Wiley \& Sons, Inc.: New York, NY, USA, 2007; ISBN 9780470038567.

75. Nunnaly, J. Psychometric Theory; McGraw-Hill: New York, NY, USA, 1978; ISBN 00704746569780070474659.

76. PEFC Slovakia ND SFCS 005 Vzdelávanie Účastníkov Certifikačného Procesu Pre Uplatňovanie Slovenského Systému Certifikácie Lesov. Available online: https:/ / www.pefc.sk/images/stories/files/ND_SFCS_005. pdf (accessed on 2 February 2018).

77. Giessen, L.; Burns, S.; Sahide, M.A.K.; Wibowo, A. From governance to government: The strengthened role of state bureaucracies in forest and agricultural certification. Policy Soc. 2016, 35, 71-89. [CrossRef]

78. Kovalčík, M. Efficiency of the Slovak forestry in comparison to other European countries: An application of Data Envelopment Analysis. Cent. Eur. For. J. 2018, 64, 46-54. [CrossRef]

79. PEFC Slovakia TD SFCS Pravidlá Pre Certifikáciu Hospodárenia v Lesoch. Available online: https://www. pefc.sk/images/stories/files/TD_SFCS_1002_2014.pdf (accessed on 3 March 2018).

(C) 2018 by the authors. Licensee MDPI, Basel, Switzerland. This article is an open access article distributed under the terms and conditions of the Creative Commons Attribution (CC BY) license (http:/ / creativecommons.org/licenses/by/4.0/). 